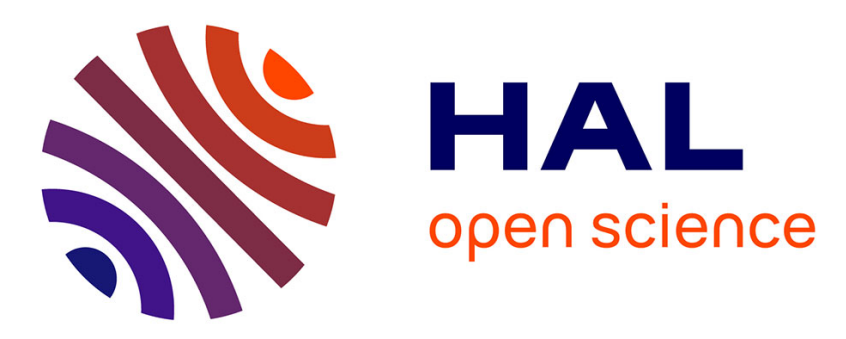

\title{
The South Millevaches Middle Carboniferous crustal melting and its place in the French Variscan Belt
}

Michel Faure, Eugène Be Mezeme, Alain Cocherie, Jérémie Melleton, Philippe Rossi

\section{- To cite this version:}

Michel Faure, Eugène Be Mezeme, Alain Cocherie, Jérémie Melleton, Philippe Rossi. The South Millevaches Middle Carboniferous crustal melting and its place in the French Variscan Belt. Bulletin de la Société Géologique de France, 2009, 180 (6), pp.473-481. 10.2113/gssgfbull.180.6.473 . insu00352085

\section{HAL Id: insu-00352085 \\ https://hal-insu.archives-ouvertes.fr/insu-00352085}

Submitted on 12 Jan 2010

HAL is a multi-disciplinary open access archive for the deposit and dissemination of scientific research documents, whether they are published or not. The documents may come from teaching and research institutions in France or abroad, or from public or private research centers.
L'archive ouverte pluridisciplinaire HAL, est destinée au dépôt et à la diffusion de documents scientifiques de niveau recherche, publiés ou non, émanant des établissements d'enseignement et de recherche français ou étrangers, des laboratoires publics ou privés. 
The South Millevaches Middle Carboniferous crustal melting and its place in the French Variscan Belt

Michel Faure ${ }^{1}$, Eugène Bé Mézème ${ }^{1,2}$, Alain Cocherie ${ }^{2}$, Jérémie Melleton ${ }^{1,2}$, and Philippe Rossi ${ }^{2}$

1. Institut des Sciences de la Terre d'Orléans (ISTO), UMR CNRS- Université d'Orléans 6113, Campus Geosciences, 1A Rue de la Férollerie, 45071 Orléans Cedex 2

2. BRGM, Av. Claude-Guillemin, BP 36009, 45060 Orléans Cedex 2, France

Corresponding author: Michel.Faure@univ-orleans.fr

Abstract: Several episodes of crustal melting are now well identified in the Variscan French Massif Central. Middle Devonian (ca 385-375 Ma) migmatites are recognized in the Upper and Lower Gneiss Units involved in the stack of nappes. Late Carboniferous migmatites (ca $300 \mathrm{Ma}$ ) are exposed in the Velay Massif only wilst and Middle Carboniferous migmatites crop out in the ParaAutochthonous Unit and Southern Fold-and-Thrust Belt. In the SW part of the Massif Central, the South Millevaches massif exposes migmatites developed at the expense of ortho- and paragneiss. Theform kilometer-sized septa within the foliated Goulles leucogranitic pluton, which is in turn intruded by the non-foliated Glény two micas granite pluton. Monazite grains extracted from these three rock-types have been dated by the EPMA chemical method. Three samples of migmatite yield a late Visean age (ca 337-328 Ma), the Goulles and Glény granitic plutons yield ages at 324$323 \mathrm{Ma}$ and 324-318 Ma, respectively. These new results enlarge the evidence of a Middle Carboniferous crustal melting imprint that, up to now was only reported in the eastern part of the French Massif Central, in the northern Cévennes and in the Montagne Noire axial zone. At the scale of the French Variscan massifs, the Visean crustal melting event is conspicuously developed 
since it is recognized from the Massif Armoricain (Vendée and south coast of Brittany) to the Central Vosges. This episode is synchronous with the huge thermal event responsible for the “Tuffs anthracifères" magmatism of the northern Massif Central and Vosges, and took place immediately after the last thickening phase recorded both in Montagne Noire and Ardennes, this is on the southern and northern outer zones of the Variscan Belt, respectively. However, the geodynamic significance of this major event is not fully understood yet.

Key-words: Crustal melting, Monazite U-Th-Pb chemical dating, Variscan Belt, French Massif Central

La fusion crustale sud-Millevaches et sa place dans la chaîne varisque française Mots-clés: fusion crustale, monazite, datation chimique U-Th- $\mathrm{Pb}$, chaîne varisque, massif central français

Résumé. Plusieurs épisodes de fusion crustale sont maintenant bien identifiés dans la chaîne varisque du massif Central Français. Des migmatites d'âge Dévonien moyen (385-375 Ma) sont reconnues dans les Unités Supérieures et Inférieures des Gneiss qui sont impliquées dans la pile de nappes. Des granites d'anatexie et des migmatites datés du Carbonifère Supérieur (300 Ma) affleurent uniquement dans le Velay; et des migmatites d'âge Carbonifère Moyen se développent dans l'Unité Para-autochtone et l'avant-pays plissé. Dans le Sud du massif de Millevaches, des migmatites issues de la fusion crustale d'ortho- et de paragneiss affleurent sous forme de grands septa inclus dans le pluton de leucogranite folié de Goulles qui est à son tour recoupé par le pluton de leucogranite non-folié de Glény. Des monazites extraites des ces trois types lithologiques ont 
été datées par la méthode chimique à la microsonde électronique. Trois échantillons de migmatite donnent des âges compris entre 337 Ma et 328 Ma. Les plutons granitiques de Goulles et de Glény fournissent respectivement des âges de 324-323 Ma et de 324-318 Ma. Ces nouveaux résultats augmentent le domaine concerné par la fusion crustale du Carbonifère moyen qui, jusqu'à présent n'était connue que dans l'est du Massif Central, au nord des Cévennes et dans la zone axiale de la Montagne Noire. A l'échelle des massifs varisques français, la migmatisation du Viséen est reconnue du Massif Armoricain (Vendée, Bretagne méridionale) aux Vosges centales. Cet épisode est contemporain de l'important événement thermique responsable du magmatisme des “Tufs anthracifères" du Nord du Massif Central et des Vosges. Il se situe immédiatement après la dernière phase importante d'épaississement reconnue dans les deux domaines externes méridionaux et septentrionaux de la chaîne, en Montagne Noire et dans les Ardennes. Cependant, la signification géodynamique de cet événement majeur de l'orogenèse varisque n'est pas encore bien comprise.

\section{INTRODUCTION}

All along its Late Paleozoic evolution, the French Massif Central (FMC) experienced several episodes of crustal melting. The earliest synorogenic plutonism is represented by the peraluminous biotite-cordierite Guéret-type plutons dated as Late Devonian-Early Carboniferous (Berthier et al., 1979; Duthou et al., 1984). In the northern part of the FMC, the Visean magmatism is represented by the "Tufs Anthracifères" series. Acidic and intermediate lavas are associated with terrigeneous rocks (sandstone, mudstone, conglomerate and some coal measures). The sedimentary rocks bear paleontological assemblages of Late Visean age. Numerous dykes, microgranites and granitoids ( the so-called "red-granites") represent the deep magmatic equivalent of this series. These are dated at 335-330 Ma by U-Pb zircon, whole rock $\mathrm{Rb} / \mathrm{Sr}$ and $\mathrm{Sm} / \mathrm{Nd}$ methods (Duthou et al., 1984; Binon et Pin, 1989; Pin and Duthou, 1990). During the Late Carboniferous (NamurianWestphalian), the entire FMC underwent a widespread plutonic event characterized by two main rock types. Two micas peraluminous granites are exposed in the NW (i.e. Limousin), and 
porphyritic monzogranites dominantly crop-out in the SE (i.e. Margeride-Cévennes). U-Pb zircon and U-Th-Pb monazite ages in both rock types range between 325-310 Ma (e.g. Duthou et al., 1984, Pin and Duthou, 1994; Faure, 1995; Brichaud et al., 2007; Bruguier, 1998; Joly et al., 2007).

Crustal melting is also represented by three generations of migmatites and anatectic granitoids. The oldest one develops in Devonian (ca 385-375 Ma), before the emplacement of the Guéret-type granite. This anatectic event is associated with the exhumation of high pressure rocks during the eo-Variscan event (e.g. Pin and Peucat, 1986; Faure et al., 2008 and enclosed references). A second migmatitic event is known in the northern part of the Cévennes region, and in the Montagne Noire axial zone (Cocherie et al., 2005; Bé Mézème et al., 2005, 2006). Although rarely emphasized in previous works, this crustal melting event, which is roughly coeval with the Tufs Anthracifères magmatism, plays a major role in the evolution of the Variscan Massif Central. The third, and last, migmatitic event is located in the Velay dome only, where it partly overprints the Middle Carboniferous North Cévennes migmatites. The Velay cordierite migmatites and associated cordierite granitoids yield ages around $300 \mathrm{Ma}$ (e.g. Ledru et al., 2001).

The understanding of the tectonic, metamorphic and magmatic evolution of the French Massif Central made significant advances due to increase in detail mapping, and in petro-structural and geochronological studies. Age determination is a key point to settle any interpretation, but the available data base remains limited, and thus several areas are still poorly understood due to the lack of accurate time constraints. This paper deals with new monazite U-Th-Pb chemical dating of the migmatites and peraluminous plutons that crop out in the southern part of the Millevaches Massif (Fig. 1). Although recognized since a long time (Monier, 1980; Monier et al., 1980; Labernardière, 1992), these rocks remained undated. This allows us to provide a better chronological and geological frame for the emplacement of the South Millevaches migmatites, and thereby of the Eastern French Massif Central.

\section{GEOLOGICAL SETTING}


The stack of nappes of the FMC results of several tectonic-metamorphic events. From bottom to top, and basically from South to North, five principal units are recognized (e.g. Ledru et al., 1998; Faure et al., 2005, Fig. 1): 1) the foreland sedimentary basin, 2) the fold-and-thrust belt; 3) the Para-autochthonous Unit, 4) the Lower Gneiss Unit, 5) the Upper Gneiss Unit. In the northern part of the FMC, the metamorphic nappes are unconformably overlain by the Late Visean (ca. 330Ma) "tufs anthracifères" series.

\section{The South Millevaches area}

In the western Massif Central, or Limousin area, the nappe stack is cross-cut by ductile normal faults, such as the Argentat and Nantiat ones, the activity of which is coeval with the emplacement of leucogranite plutons (e.g. Faure, 1995). The Argentat fault is a polyphase structure (Floc'h, 1983; Labernardière, 1992; Roig et al., 2002; Fig. 2). The Late Carboniferous (Stephanian) brittle left-lateral motion is associated with the opening of pull-apart coal basins. The Late Visean-Namurian tectonic activity of the Argentat fault occurred as a ductile normal motion responsible for the exhumation of the eastern part (Millevaches plateau) with respect to the western one (Limousin region). East of the Argentat fault, in the footwall, the Millevaches plateau consists of several granitic plutons and subordinate metamorphic country rocks (Lameyre 1966; Floc'h, 1983; Monier, 1980, Monier et al., 1980; Feix, 1988; Labernardière 1992) belonging to the Para-autochthonous Unit. The Millevaches plateau is subdivided into an eastern and western part by the NNW-SSE ductile dextral Pradines wrench fault (Gébelin et al., 2007). The main leucogranitic massif, the Goulles pluton, is a two micas medium grained granite with rare garnet that exhibits a well marked mineral preferred orientation (Fig. 3). The pluton contains also numerous micaschist xenoliths concordant with the mineral fabric. The granite preferred orientation developed under sub-solidus conditions progressively evolves into a post-solidus planar foliation up to a mylonitic fabric when approaching the Argentat fault.

The Glény pluton is a nearly isotropic fine grained granite with biotite, dominant upon muscovite, zoned plagioclase, and rarely perthitic K-feldspar. It forms a $5 \mathrm{~km}$-long massif 
elongated in the E-W direction and bounded to the east by the Pradines fault. From the structural point of view, this massif appears as a late pluton since it cross-cuts at high angle the host rock foliation and the Goulles pluton.

The Gour Noir pluton consists of a two micas porphyritic granite. K-Feldspar megacrysts and biotite define a sub-solidus foliation, the development of which is consistent with the dextral motion of the Pradines fault (Monier et al., 1980; Gébelin et al., 2007). Furthermore, myrmekite developed along the long faces of K-feldspar argue for a magmatic foliation coeval with melt crystallization (e.g. Hibbard, 1986; Simpson and Wintsch, 1989).

The granite host rocks consist of biotite ( \pm garnet) micaschists, quartzite and augen orthogneiss (called the Xaintrie orthogneiss) that yield a whole rock Rb-Sr age of $467 \pm 8 \mathrm{Ma}$ (Monier, 1980, Labernardière, 1998). After ductile shearing, the orthogneiss experienced a partial melting. In most of the outcrops, the rock is a metatexite bearing a dominant NNW-SSE trending foliation but variable dips (Fig. 2). Restites of the orthogneissic protolith or isolated K-feldspar augens and biotitic aggregates are conspicuous in the migmatite (Fig. 3).

\section{MONAZITE U-Th-Pb RADIOMETRIC STUDY}

\section{Monazite U-Th-Pb chemical ages}

Over the past fifteen years, owing to technological progress performed on electron microprobe measurements, chemical geochronology on monazite has been made possible (e.g. Suzuki and Adachi, 1991; Montel et al., 1996; Cocherie et al., 1998, 2005). Due to its high U-Th contents and negligible common $\mathrm{Pb}$ content (Parrish, 1990), monazite is one of the frequently used phases in geochronology. This use as radiochronometer is also enhanced by the restricted lead diffusion in monazite lattice (Montel et al., 1996; Cocherie et al., 1998) and by its high temperature stability up to more than $900^{\circ} \mathrm{C}$ (Braun et al., 1998). Scanning electron microprobe (SEM) in Back-Scattered Electron (BSE) mode is one of the best means to distinguish mineral species present in thin section. Within a single monazite grain, SEM allows us to recognize microinclusions, altered domains and all other components of non-monazite composition. Providing 
contrasted chemical composition of monazite, SEM can also help to define heterogeneous compositional domains, which can be related to inheritance phenomenon during successive episodes of crystallization. Detailed analytical procedure is described in Cocherie et al. (1998). Theoretical procedure to reduce the data and to calculate the average age from individual spot analyses is given by Cocherie and Albarède (2001), Cocherie et al. (2005) and Cocherie and Legendre (2007). The analyzed grains in thin section, described below, were prepared and analyzed by a Cameca SX 50 EPMA co-operated by BRGM-CNRS-Orléans University. The 2 $\sigma$ errors given on individual ages depend on $\mathrm{U}, \mathrm{Th}$, and $\mathrm{Pb}$ contents and are calculated by propagating the uncertainties of these elements (at 95\% confidence level). However, because the mean age of an homogeneous age population can be calculated directly from the isochron plot $\mathrm{Th} / \mathrm{Pb}$ vs $\mathrm{U} / \mathrm{Pb}$, only the uncertainty on these two parameters $(\mathrm{Th} / \mathrm{Pb}$ and $\mathrm{U} / \mathrm{Pb})$ are required to calculate the uncertainty on the mean age. Age calculations were done using the Isoplot/Ex (3.1) program of Ludwig (2004) and a Microsoft Excel add-in program for determining U-Th- $\mathrm{Pb}$ ages from EPMA measurements (Pommier et al., 2002).

\section{Sample description}

\section{Migmatites}

Three migmatites have been sampled (cf. Fig. 2 and Table 1 for location). In thin section, all samples exhibit a planar mineral preferred orientation marked by biotite clots, polycrystalline quartz aggregates with recrystallized grains and slightly serrated grain boundaries, K-feldspar is elongated and sometimes cataclased. Fibrolitic sillimanite develops around biotite, muscovite flakes are generally oblique to the foliation. Apatite, zircon, monazite, xenotime, allanite and oxides are common accessory phases. Monazite occurs as inclusion in biotite. SEM-BSE observations show that the grains are subeuhedral without chemical growth zoning and are slightly fractured (Fig. 4). 


\section{Granitoids}

Two samples from biotite-rich, fine grained Glény pluton and two from the Goulles leucogranitic pluton have been analyzed (Table1). Under the microscope, the minerals from the Glény granite are undeformed. Globular quartz grains do not exhibit any mark of dynamic recrystallization. Zircon and monazite which are the main accessory phases, are observed as inclusions within biotite. In the Goulles leucogranite, quartz grains form elongated polycrystalline aggregates with serrated or planar grain boundaries. Fibrolitic sillimanite is also present. K-feldspar megacrysts are surrounded by a fine grained matrix of quartz, plagioclase and muscovite. Zircon, monazite, apatite and allanite occur either as interstitial phases, along biotite grain boundaries or as inclusions in biotite. Monazites in the Goulles and Glény plutons are abundant but exhibit small sizes, around 40 $\mu \mathrm{m}$. SEM-BSE observations of the monazite grains indicates a subhedral outline with a slight zonation in some of them (Fig. 5). For each sample, one single grain population has been recognized.

\section{Results}

For each migmatite sample, monazite grains have been separated by crushing, sieving and heavy liquids. Monazite grain size ranges from 20 to $70 \mu \mathrm{m}$. Five to eight grains have been analyzed with 76 to 129 point analyzes. The age yielded by the three migmatite samples are similar within the error, and allows us to constrain the age of crustal melting between 337 and $328 \mathrm{Ma}$ (Fig. 6).

Furthermore, 9 and 7 grains from each sample of the Glény granite yield $324 \pm 3 \mathrm{Ma}$ and $318 \pm 3$ Ma (Fig. 7) which are similar within errors. This allow us to propose a ca $321 \mathrm{Ma}$ age for the post-migmatitic plutonism. The two samples of the Goulles leucogranite yield quite similar ages of $324 \pm 3 \mathrm{Ma}$ and $323 \pm 4 \mathrm{Ma}$ (Fig. 7). On the basis of these monazite $\mathrm{U}-\mathrm{Th}-\mathrm{Pb}$ ages, it is not possible to distinguish the emplacement age of the Glény pluton from that of the Goulles pluton since they overlap within the errors. However field relationships indicates that the Glény pluton intrudes the Goulles pluton. Conversely, the migmatization age, around $334 \mathrm{Ma}$, is about $10 \mathrm{Ma}$ 
older than the leucogranite emplacement age (around $324 \mathrm{Ma}$ ). The 7 age data are summarized in figure 8 and Table 1.

\section{DISCUSSION-CONCLUSION}

This radiometric study demonstrates the existence of a widespread Middle Carboniferous (Visean) partial melting event in the South Millevaches massif. Our datings allow us to rule out a Devonian age for this anatexis by contrast to the ages recovered from the the Upper and Lower Gneiss Units in the nearby Limousin (Faure et al., 2008). However, the restricted size of the area exposing these Carboniferous migmatites does not allow us to better characterize their structural setting. Presently, the migmatitic foliation trends NNE-SSW with variables dips (Fig. 2), but this attitude has likely been reworked by the emplacement of the Goulles leucogranitic pluton and thus does not reflect its primary geometry. Nevertheless, the South Millevaches migmatites represent and important pin-point in the French Variscan Belt.

Visean migmatites were already recognized in several parts of the FMC (Fig. 9). The largest area is the Montagne Noire axial zone (Gèze, 1953; Soula et al., 2001), where migmatites crop out in the core of a $50 \mathrm{~km}$ long migmatitic dome. More to the North, in the Cévennes, Carboniferous migmatites are dated at 330 -325 Ma (Cocherie et al. 2005; Bé Mézème et al., 2005, 2006). But due to their limited outcrop area, their bulk architecture remains unknown. To the west of the Massif Central, Visean migmatites are known in the in the southern part of the Massif Armoricain (Turrillot et al., in press). To the east, ca 340 Ma migmatites are also identified in Central Vosges (Schaltegger et al., 1999).

As stated above, in the FMC, the Late Visean anatetic event is coeval with the Tufs Anthracifères magmatism. Both phenomena represent the shallow and deep records of a same crustal melting event that took place in the same time span as North-directed and South-directed thrusting in the Ardenne and Montagne Noire massives, respectively (Fig. 9). It is well established that in response to crustal thickening, release of heat and fluids may trigger crustal melting. Such a scheme satisfactorily accounts for the Namurian-Westphalian leucogranite 
emplacement in an extensional setting (e.g. Faure, 1995; Ledru et al., 2001; Talbot et al., 2005;

Joly et al., 2008). Conversely, in most of areas, the tectonic setting of the Late Visean migmatite is poorly constrained or controversial (e.g. Soula et al., 2001). 
It is also worth to note that the location of the Montagne Noire, Northern Cévennes or S. Millevaches migmatites in the outer zone of the FMC is rather unusual since migmatites generally crop out in the inner zone of an orogen where the crust has been thickened. The collapse of previously thickened continental crust is often invoked to explain the development of migmatites. In the case of the FMC, late collisional extension cannot be the only cause of the Late Visean partial melting : i.e. volcanism, plutonism and anatexis. On the basis of geochemistry, it has been shown that crustal thickening alone is unable to induce the thermal anomaly responsible for the Late Visean magmatism, thus, a mantle heat source has been put forward (Pin and Duthou, 1990; Ledru et al., 2001; Faure et al., 2002). As suggested for the Schwarzwald-Vosges segment (Eisbacher et al., 1989), we propose that the required mantle contribution is due to a decoupling between continental crust and lithospheric mantle. At the end of the Variscan collision, the delamination of the lithospheric mantle along the Moho discontinuity will allow the uprise of the asthenosphere that in turn will provide the necessary thermal input, and fluids to trigger crustal melting. Mantle delamination can be an efficient mechanism accounting for the Late Visean thermal event in the entire Variscan massifs. However, this interpretation remains a working hypothesis to be tested by forthcoming works.

Finally, the Late Visean age of the S. Millevaches migmatite and the Namurian age of the subsequent granitic plutons comply well with the geochronological data regarding crustal melting available from the French Variswcan massifs. These new results emphasize the importance of synto post-orogenic crustal melting events in this orogen. Nevertheless, further works are still needed to settle a comprehensive geodynamic interpretation of crustal melting at the scale of the French Variscan belt. 


\section{References}

Bé MÉzÈme E., FAure M. Y. Cocherie A. \& Chen Y. (2005). - In situ chemical dating of superimposed tectonic and magmatic events in the French Variscan Belt. - Terra Nova, 17, 420426.

Bé Mezème E., Cocherie A., FAure M., Legendre O. \& Rossi P. (2006). - Electron microprobe monazite geochronology: a tool for evaluating magmatic age domains. Examples from the Variscan French Massif Central. - Lithos, 87, 276-288.

Berthier, F., Duthou JL. \& Roques M. (1979). - Datation géochronologique Rb/Sr sur roches totales du granite de Guéret (Massif Central). Age fini-Dévonien de mise en place de l'un de ses faciès types. - Bull. Bur. Rech. Géol. Min. Fr.,1, 31-42.

BINON M. \& PIN C. (1989). - Géochronologie Rb-Sr et U-Pb des granites du Mayet de Montagne et des Bois Noirs, Montagne Bourbonnaise. - Bull. Soc. Géol. France, 5, 695-703.

Brichaud S., ReSPAUt JP. \& MoniÉ P. (2007). - New age constraints on emplacement of the Cévenols granitoids, South French Massif Central. - Int. J. Earth Sci., DOI 10.1007/s00531-0070187.

Braun I., Montel JM. \& Nicollet C. (1998). - Electron microprobe dating of monazite from high-grade gneisses and pegmatites of Kerala Khondalite Belt, Southern India. - Chem . Geol. , 146, 65-85.

Bruguier O, BecQ-Giraudon, JF., Bosch D. \& J-R. LAncelot JR. (1998). - Late Visean (upper Missisipian) hidden basins in the internal zones of the Variscan Belt : U-Pb zircon evidence from the French Massif Central. - Geology, 26, 627-630. 
Cocherie A. \& AlbArÈDE F. (2001). - An improved U-Th-Pb age calculation for electron microprobe dating of monazite. - Geochim. Cosmochim. Acta, 65, 4509-4522.

Cocherie, A. \& Legendre O. (2007), Potential minerals for determining U-Th-Pb chemical age using electron microprobe. Lithos, 93, 288-309.

Cocherie, A., Legendre O., Peucat JJ. \& Kouamelan A. (1998). - Geochronology of polygenetic monazites constrained by in situ electron microprobe Th-U-total $\mathrm{Pb}$ determination: Implications for lead behaviour in monazite. - Geochim. Cosmochim. Acta, 62, 2475-2497.

Cocherie A., Be Mezeme E., Legendre O., Fanning M., Faure M. \&Rossi P. (2005). - Electron microprobe dating as a tool for understanding closure of $\mathrm{U}-\mathrm{Th}-\mathrm{Pb}$ system in monazite from migmatite. - American Mineralogist, 90, 607-618.

Duthou Jl., Cantagrel JM., Didier J. \& Vialette Y. (1984). - Palaeozoic granitoids from the French Massif Central: age and origin studied by ${ }^{87} \mathrm{Rb}-{ }^{87} \mathrm{Sr}$ system. - Physics of the Earth and Planetary Interiors, 35, 131-144.

EISBACHER G., LÜSCHEN E. \& WiCKERT F. (1989). - Crustal-scale thrusting and extension in the Hercynian Schwarzwald and Vosges, Central Europe.- Tectonics, 8, 1-21.

FAURE M. (1995).- Late orogenic carboniferous extensions in the variscan French Massif Central. Tectonics, 14, 132-153. 
Faure M., Monié, P., Maluski, H., Pin, C. \& LeloiX, C. (2002). - Late Visean thermal event in the northern part of the French Massif Central. New ${ }^{40} \mathrm{Ar} /{ }^{39} \mathrm{Ar}$ and $\mathrm{Rb}-\mathrm{Sr}$ isotopic constraints on the Hercynian syn-orogenic extension.- Int. J. Earth Sciences, 91, 53-75

Faure M., Be Mezeme E., Duguet M., Cartier C., Talbot J-Y. (2005). - Paleozoic tectonic evolution of medio-Europa from the example of the French Massif Central and Massif Armoricain. In: (eds.) Carosi, R., Dias, R., Iacopini, D., and Rosenbaum, G., The southern Variscan belt, Journal of the Virtual Explorer, Electronic Edition, ISSN 1441-8142, 19, Paper 5.

FEIX I. (1988). - Etude géologique dans le sud Millevaches: lithologie, géochimie, métamorphisme et structure des series métamorphiques situées au sud de la vallée de la Dordogne. Place dans le Massif central français occidental. Thèse Univ. d'Orléans, 535pp.

FLOC'H JP. (1983). - Le socle métamorphique du Limousin central: une traverse de la branche ligérienne de l'orogène varisque de l'Aquitaine à la zone broyée d'Argentat (massif central français), thèse Univ. Limoges. 445pp.

Gebelin A., Brunel M., Monie P., FAure M. \& Arnaud N. (2007). - Transpressional tectonics and Carboniferous magmatism in the Limousin, Massif Central, France:structural and ${ }^{40} \mathrm{Ar} /{ }^{39} \mathrm{Ar}$ investigations. - Tectonics , 26, DOI: 10.1029/2005/TC00822, 2007.

Geze B. (1953). - Etude Géologique de la Montagne Noire et des Cévennes Méridionales. Mem. Soc. Géol. France, 24, 215.

HIBBARD, M.J. (1986). - Deformation of incompletely crystallized magma systems: Granitic gneisses and their tectonic implications. - Journal of Geology, 95, 543-561. 
Joly A., Chen, Y., Faure, M. \& Martelet, G. (2007). A multidisciplinary study of a syntectonic pluton close to a major lithospheric-scale fault: relationships between the Montmarault granitic massif and the Sillon Houiller Fault in the Variscan French Massif Central. Part I: Geochronology, mineral fabrics and tectonic implications. - J. Geophys. Res., 112, B10104.

LABERNARDIERE H. (1992). Carte géologique 1/50 000 Argentat, BRGM, Orléans 70p.

LAMEYRE J. (1966). Leucogranites et muscovitisation dans le massif central français. Ann. Fac. Sci. Univ. Clermont-Ferrand, 29, 264pp.

Ledru P., Lardeaux, JM. Santallier D., Autran A. Quenardel JM. Floc'h JP., Lerouge G., Maillet N., Marchand J. \& Ploquin A. (1989).- Où sont les nappes dans le Massif Central français? - Bull. Soc. géol. France, 8, 605-618.

Ledru, P. Courrioux G., Dallain C., Lardeaux JM., Montel JM., Vanderhaeghe O., \& Vitel G. (2001). - The Velay dome (French Massif Central): melt generation and granite emplacement during orogenic evolution. Tectonophysics, 342, 207-237.

LUDWIG K.R. (2000). - Users Manual for Isoplot/Ex. version 2.00, A geochronological toolkit for Microsoft Excel, Berkeley Geochronology Center. Spec. Pub. 1a, 43 pp.

MATTE P. (1986). - La chaîne varisque parmi les chaînes paléozoïques péri-atlantiques, modèle d' évolution et position des grands blocs continentaux au Permo-Carbonifère. - Bull. Soc. Géol. France, 8, 9-24.

Monier G. (1980). - Pétrologie des granitoïdes du Sud Millevaches, Massif central français. Minéralogie, géochimie, geochronology. Thèse $3^{\circ}$ cycle, Clermont-Ferrand, 288p. 
Monier G., Labernardiere H. \& Duthou JL. (1980). - Les granitoïdes du Sud Millevaches: premiers resultants cartographiques et pétrographiques; compositions chimiques moyennes; proposition d'une chronologie de mise en place. - Bull. Soc. Géol. France, 447-454.

Montel JM., Foret, S., Veschambre, M., Nicollet, C. \& Provost, A. (1996). Electron microprobe dating of monazite. - Chem. Geol., 131, 37-53.

PARRISH R.R. (1990). - U-Pb dating of monazite and its implication to geological problems. - Can. J. Earth Sci., 27, 1431-1450.

Pearce J. A., Harris N.B.W. \& Tindle A.G. (1984).- Trace element discrimination for the tectonic interpretation of granitic rocks. - J. of Petrology, 25, 956-983.

Pin C., \& PeuCAT JJ. (1986). - Ages des épisodes de métamorphisme paléozoïques dans le Massif central et le Massif armoricain. - Bull. Soc. Geol. France, 8, 461-469.

PIN C. \& Duthou JL. (1990). - Sources of hercynian granitoids from the French Massif Central: inferences from $\mathrm{Nd}$ isotopes and consequences for crustal evolution. - Chem. Geol., 83, 281-296.

Pommier A., Cocherie A. \& Legendre O. (2002). - EPMA dating Users' manual : age calculation from electron probe microanalyzer measurements of U-Th-Pb. - BRGM Internal report, Orléans, France.

RoIG, J-Y., FAURE, M. \& MALUSKI, H. (2002). - Superimposed tectonic and hydrothermal events during the late-orogenic extension in the western French massif central: a structural and ${ }^{40} \mathrm{Ar} /{ }^{39} \mathrm{Ar}$ study. -Terra Nova, 14, 25-32. 
Schaltegger U., Fanning CM., Günther D., Maurin JC., Schulmann K.\& Gebauer D. (1999). - Growth, annealing and recrystallization of zircon and preservation of monazite in high grade metamorphism: conventional and in-situ U-Pb isotope, cathodoluminescence and microchemical evidence. - Contrib. Mineral. Petrol., 134, 186-201.

SIMPSON C. \& WINTSCH RP. (1989). - Evidence for deformation induced K-feldspar replacement by myrmekite. - J. Metam. Geol., 7, 261-275.

Soula J.C., Debat P., Brusset S., Bessière G., Christophoul F. \& Déramond J. (2001). Thrust-related, diapiric and extensional doming in a frontal orogenic wedge: example of the Montagne Noire, Southern French Hercynian Belt. - J. Struct. Geol., 23, 1677-1699.

SUZUKI K., \& ADACHI M. (1991). - Precambrian provenance and Silurian metamorphism of the Tsubonosawa paragneiss in the South Kitakami terrane, Northeast Japan, revealed by the chemical Th-U-total Pb isochron ages of monazite, zircon and xenotime. - Geochemical J., 25, 11-37.

Talbot J-Y., Faure M., Chen Y., Martelet G. (2005). - Pull apart emplacement of the Margeride granitic complex (French Massif Central). Implications for the Late evolution of the Variscan orogen. - J.Struct. Geol., 27, 1610-1629.

Tera F. \& Wasserburg G.J. (1972). - U-Th-Pb systematics in three Apollo 14 basalts and the problem of initial $\mathrm{Pb}$ in lunar rocks. - Earth Planet Sci Lett., 14, 281-304.

Turrillot P., Augier R. \& FAure M. in press. The top-to-the-East Sarzeau Shear Zone and its place in the syn-orogenic extensional tectonics of Southern Armorica. Bull. Soc. Géol. France. 
WENDT I. \& CARL C. (1991). - The statistical distribution of the mean squared weighted deviation. - Chem. Geol, (Isot. Geosci. Sect.) 86, 275-285.

Wiedenbeck M., P., Allé P., F. Corfu F., Griffin Wl., Meier M., Oberli, F. von Quadt A., RodDICK JC \& SPIEGEL W. (1995). - Three natural zircon standards for U-Th-Pb, Lu-Hf, trace element and REE analysis. - Geostandards Newsletter, 19, 1-23.

WiLlLiams I.S. (1998). - U-Th-Pb Geochronology by Ion Microprobe. - Reviews of Eco. Geol., 7, $1-35$.

ZHU, X.K. \& O’NiONS RK. (1999). - Zonation of monazite in metamorphic rocks and its implications for high temperature thermochronology: a case study from the Lewisian terrain. Earth Planet. Sci. Letters, 171, 209-220. 
Figure captions

Fig. 1: Structural map of the French Massif Central (from Ledru et al., 1989; Faure et al., 2005), with emphasis on Middle Carboniferous migmatites.

Fig. 1: Schéma structural du Massif central français (d'après Ledru et al., 1989 ; Faure et al., 2005) montrant la position des migmatites d'âge Carbonifère moyen.

Fig. 2: Schematic map of the south Millevaches area (East of Argentat) with location of the dated samples. Cross section of the study area from Limousin to eastern Millevaches massif through the Argentat fault.

Fig. 2: Carte schématique du domaine sud Millevaches (à l'est d'Argentat) et localisation des échantillons datés. Coupe du Limousin à l'est Millevaches à travers la faille d'Argentat.

Fig. 3: Photographs of migmatites and granitoids. A: metatexite (sample smv 12), the dated monazite grains come from the leucosomic part of this rock. B: well foliated metatexite in which K feldspar augens from the orthogneiss protolith are still recognizable. The foliation is deformed by post-migmatitic shear bands indicating a dextral sense of shear. C: Goulles leucogranite exhibiting a well defined magmatic layering. D: Goulles leucogranite containing boudinaged micaschist xenoliths belonging to the para-autochthonous Unit that form the pluton country rock.

Fig 3: Aspect de terrain des migmatites et granitoïdes. A: métatexite, (échantillon smv 12), les grains de monazite dates proviennent de la partie leucocrate de la roche. B: Métatexite montrant des reliques de clastes de mégacristaux du protolithe orthogneissique. La foliation est déformée par des bandes de cisaillement dextres développées dans des conditions post-solidus après l'anatexie. C: leucogranite de Goulles présentant un rubanement magmatique bien développé. D: leucogranite de Goulles contenant des enclaves boudinées de micaschiste appartenant à l'Unité para-autochtone qui constitue l'encaissant du pluton. 
Fig. 4: SEM-BSE images of the analyzed monazites in migmatites. Monazite grains are included into biotite developed during leucosome crystallization.

Fig. 4: Images MEB en mode rétrodiffusé des monazites analysées dans les migmatites. Les grains de monazite sont inclus dans des biotites formées pendant la cristallisation du leucosome.

Fig. 5: SEM-BSE images of the analyzed monazites in the Goulles leucogranite. Grains are subeuhedral. Except for grains g1 and g2 where a thin rim can be observed, all grains are devoid of magmatic zoning.

Fig. 5: Images MEB en mode rétrodiffusé des monazites analysées dans le leucogranite de Goulles. Les grains sont subautomorphes. A l'exception des grains g1 et g2, aucune zonation magmatique n'est visible.

Fig. 6: Isochron plot obtained from the analysis of monazite grains from three migmatite samples (see location in fig. 2).

Fig. 6: Diagrammes isochrones des monazites dans les trois échantillons de migmatites analysées (voir localisation sur la fig. 2)

Fig. 7: Isochron plot obtain from the analyses of monazite grains from the Goulles and Glény granites (see location in fig. 2).

Fig. 7: Diagrammes isochrones des monazites dans les échantillons du leucogranite de Goulles et de Glény (voir localisation sur la fig. 2).

Fig.8: Synoptic table of the dated migmatites and granitoids samples in the South Millevaches area Fig. 8: Tableau synoptique des échantillons de migmatites et de granitoïdes dates dans le Sud Millevaches.

Fig. 9: Distribution of the Visean migmatites in the French Variscan Belt. 
Fig. 9: Carte de la distribution des migmatites d'âge viséen dans la chaîne varisque française. 
Table 1. Sample location and average ( \pm Standard Deviation) chemical composition of analyzed monazite. n: number of analyzes.

$\begin{array}{lcccccr}\text { Sample } & \text { Location } & \mathrm{Pb}(\mathrm{ppm}) & \mathrm{U}(\mathrm{ppm}) & \mathrm{Th}(\mathrm{ppm}) & \mathrm{Th} / \mathrm{U} & \text { isochron } \\ \text { age } \mathrm{n} & \pm & \pm & \pm & \pm & 2 \sigma(\mathrm{Ma})\end{array}$

\section{Migmatite}

Smv 4

$\begin{array}{llllll}4^{\circ} 05^{\prime} 09^{\prime \prime} & 1176 \pm 208 & 6762 \pm 3064 & 57477 \pm 8026 & 11 \pm 8 & 334 \pm 4\end{array}$

90

$002^{\circ} 03^{\prime} 18.6^{\prime \prime}$

$\begin{array}{lllllll}\text { Smv } 11 & 45^{\circ} 09^{\prime} 07^{\prime}, & 1380 \pm 276 & 4035 \pm 3627 & 81726 \pm 13506 & 41 \pm 31 & 328 \pm 3\end{array}$

129

$002^{\circ} 00^{\prime} 29.8^{\prime \prime}$

$\begin{array}{clrrrrr}\text { Smv } 12 & 45^{\circ} 07^{\prime} 57^{\prime \prime} & 1326 \pm 255 & 4096 \pm 3790 & 75199 \pm 15571 & 39 \pm 27 & 337 \pm 4 \\ 76 & 002^{\circ} 01^{\prime} 02^{\prime \prime} & & & & \end{array}$

Goulles pluton

Smv 15

$45^{\circ} 07^{\prime} 25.3^{\prime \prime}$

$1745+370$

$12410 \pm 8402 \quad 80841 \pm 32275 \quad 15 \pm 18$

$324 \pm 3$

100

$002^{\circ} 01^{\prime} 05.7$ “

Smv 16

$45^{\circ} 03^{\prime} 48.2^{\prime \prime}$

$1731 \pm 281$

$17039 \pm 7749$

$65018 \pm 15616 \quad 7 \pm 11$

$323 \pm 4$

$001^{\circ} 59^{\prime} 40.1^{\prime \prime}$

\section{Glény pluton}

Smv 1

4509'07.2”

$1388 \pm 276$

$5704 \pm 5564$

$78378 \pm 16676 \quad 28 \pm 20$

$324 \pm 3$

$002^{\circ} 00^{\prime} 29.8^{\prime \prime}$

Smv 10

$45^{\circ} 08^{\prime} 46.6 ”$

60

$002^{\circ} 00^{\prime} 28.8^{\prime \prime}$

$16069 \pm 3366 \quad 69131 \pm 17866 \quad 4 \pm 2$

$318 \pm 3$ 